\title{
Volatile matter values change according to the standard utilized?
}

\author{
Os valores de material volátil mudam de acordo com a norma utilizada? \\ Los valores de los materiales volátiles cambian según el estándar utilizado?
}

Received: 09/10/2021 | Reviewed: 09/16/2021 | Accept: 09/20/2021| Published: 10/02/2021

\author{
Diego Aleixo da Silva \\ ORCID: https://orcid.org/0000-0002-2552-7672 \\ Federal University São Carlos, Brazil \\ E-mail: diegoaleixo.florestal@gmail.com \\ Ana Larissa Santiago Hansted \\ ORCID: https://orcid.org/0000-0002-0305-8860 \\ Sao Paulo State University, Brazil \\ E-mail: ana_hansted@hotmail.com \\ Gabriela Tami Nakashima \\ ORCID: https://orcid.org/0000-0001-7437-4521 \\ Federal University São Carlos, Brazil \\ E-mail: gtnakashima@estudante.ufscar.br \\ Elias Ricardo Durango Padilla \\ ORCID: https://orcid.org/0000-0001-5864-8828 \\ Sao Paulo State University, Brazil \\ E-mail: erdurango22@gmail.com \\ Júlio César Pereira \\ ORCID: https://orcid.org/0000-0001-9833-5260 \\ Federal University São Carlos, Brazil \\ E-mail: julio-pereira@ufscar.br \\ Fabio Minoru Yamaji \\ ORCID: https://orcid.org/0000-0002-0908-8163 \\ Federal University São Carlos, Brazil \\ E-mail: fmyamaji@ufscar.br
}

\begin{abstract}
In lignocellulosic biomass, the volatile matter can vary from 65 to $85 \%$. Different standards are described in the literature for obtaining this parameter. However, it is observed that some studies of regression models have not considered these differences. They create a volatile matter content database, where the standards for obtaining the same parameter are different. Thus, the objective of the study was to verify whether different standards for volatile matter present statistically equal values. That is if they can be compared with each other, without danger of bias. For this, three types of biomasses of Brazil used were used (eucalyptus chips, pine chips, and sugarcane bagasse). The samples were collected, size reduction, size separation, and stored in the laboratory. Three standards of the American Society for Testing and Materials (ASTM D1762, ASTM E872, ASTM D3175) and one standard of the International Organization for Standardization (ISO 18123) were tested. The experimental design was completely randomized, consisting of four treatments and five replications. The central limit theorem was tested in some literature databases of the volatile matter. The results showed statistical differences when changing the type of standard used. For eucalyptus sawdust, the four standards resulted in methodologies with different averages. Still, the central limit theorem was not observed in some databases of different articles. This was explained by the non-standardization of a single standard when grouping data from different works. Therefore, different volatile content standards produce different results and when comparing values, it is important to take this assumption into account.
\end{abstract}

Keywords: Proximate Analysis; ASTM; ISO; Biomass.

\section{Resumo}

Na biomassa lignocelulósica, o teor de materiais voláteis pode variar de 65 a $85 \%$. Diferentes normas são descritas na literatura. No entanto, observa-se que em alguns estudos de modelos de regressão não consideraram essas diferenças. Eles criam um banco de dados de teor de materiais voláteis, onde as normas para obtenção do mesmo parâmetro são diferentes. Assim, o objetivo do estudo foi verificar se diferentes normas para o teor de materiais voláteis apresentam valores estatisticamente iguais. Para isso, foram utilizados três tipos de biomassas do Brasil (cavaco de eucalipto, cavaco de pinus e bagaço de cana). As amostras foram coletadas, reduzidas de tamanho, separadas de tamanho e armazenadas em laboratório. Três padrões da American Society for Testing and Materials (ASTM D1762, ASTM E872, ASTM D3175) e um padrão da International Organization for Standardization (ISO 18123) foram testados. O delineamento experimental foi inteiramente casualizado, com quatro tratamentos e cinco repetições. O teorema do limite central foi testado em algumas bases de dados da literatura de teor de materiais voláteis. Os resultados 
mostraram diferenças estatísticas ao mudar o tipo de norma utilizada. Para a serragem de eucalipto, os quatro padrões resultaram em metodologias com médias diferentes. Ainda assim, o teorema do limite central não foi observado em algumas bases de dados de diferentes artigos. Isso se explica pela não padronização de um único tipo de norma no agrupamento de dados de diferentes obras. Portanto, diferentes normas de materiais de voláteis produzem resultados diferentes.

Palavras-chave: Análise Imediata; ASTM; ISO; Biomassa.

\section{Resumen}

En biomasa lignocelulósica, el contenido de materiales volátiles puede variar del 65 al 85\%. Sin embargo, se observa que en algunos estudios de modelos de regresión no consideraron estas diferencias. Crean una base de datos de contenido de materiales volátiles, donde los estándares para obtener un mismo parámetro son diferentes. Así, el objetivo del estudio fue verificar si diferentes estándares para el contenido de materiales volátiles presentan valores estadísticamente iguales. Para ello, se utilizaron tres tipos de biomasa de Brasil (astillas de eucalipto, astillas de pino y bagazo de caña de azúcar). Las muestras se recolectaron, se redujeron de tamaño, se separaron y se almacenaron en el laboratorio. Se probaron tres estándares de la Sociedad Estadounidense de Pruebas y Materiales (ASTM D1762, ASTM E872, ASTM D3175) y un estándar de la Organización Internacional de Normalización (ISO 18123). El diseño experimental fue completamente al azar, con cuatro tratamientos y cinco repeticiones. El teorema del límite central se probó en algunas bases de datos de literatura de contenido de material volátil. Los resultados mostraron diferencias estadísticas al cambiar el tipo de estándar utilizado. Para el aserrín de eucalipto, los cuatro estándares dieron como resultado metodologías con diferentes medios. Aún así, el teorema del límite central no se observó en algunas bases de datos de diferentes artículos. Esto se explica por la no estandarización de un solo tipo de norma en la agrupación de datos de diferentes trabajos. Por lo tanto, diferentes estándares para materiales volátiles producen resultados diferentes.

Palabras clave: Análisis Inmediato; ASTM; ISO; Biomasa.

\section{Introduction}

The potential of solid biofuels can be assessed using different energy parameters. Through proximate analysis, dry biomass is divided into three energy variables: total moisture, total ash, volatile matter and fixed carbon (Hansted et al., 2016; Nakashima et al., 2017; Posom et al., 2016; Silva et al., 2015; Smith et al., 2019; Yang et al., 2017). Still, this muffle furnace methodology consists of a simple, low cost and widely used tool (Özyuğuran \& Yaman, 2017).

In natural lignocellulosic waste, $65 \%$ to $85 \%$ are volatile matter. From $0.1 \%$ to $10 \%$ correspond to the total ash of the sample, with high values reflecting contamination by impurities. The fixed carbon can represent $15 \%$ to $25 \%$ of the biomass (García et al.; 2012; Nakashima et al., 2017).

The volatile matter of biomass is the largest fraction of the raw material. Hydrogen, light hydrocarbons, tar, water, carbon monoxide, carbon dioxide are released by heating the biofuel. The presence of flammable gases initiates combustion of the material, however, the high concentration of gases prevents the formation of high temperatures (García et al.; 2012; Nogueira et al., 2000; Obernberger \& Thek, 2004).

Different types of standards are found in the literature for determining the volatile matter. The type of solid fuel analyzed defines which standard is most suitable. If the biofuel is charcoal, the standard ASTM D1762 (1984) is more suitable for the determination of volatile matter. The ASTM E872 (1982) standard adopts procedures for wood particles and the ISO 18123 (2014) standard for solid biofuels. There is also a specific standard for mineral coal and petroleum coke (ASTM D31752011), which has already been used for older research on biomass characterization (Channiwala \& Parikh, 2002; Parikh et al.; 2005).

The granulometry, the entrance direction of the sample at the muffle (horizontal or vertical), the total test time, and the position of the samples in the equipment can change from standard to standard. There is a lack of consensus in the literature for the most appropriate standard, still, there are papers that change some points of the standards (Zhang et al., 2017; Thy et al.,2009). With the increased sharing of data, scientific articles have extracted data from different works and grouped them in a database. Specifically, some regression studies grouped information on volatile matter but did not consider the difference in 
standards for extracting and group the data (Table 1). Then, predictive models of higher heating values (HHV) are created in the function of all the variables of the proximate analysis.

Table 1. Volatile matter grouped on the same basis for the construction of models of HHV.

\begin{tabular}{|c|c|c|}
\hline Data base: & Standards found: & References: \\
\hline Yin (2011) & $\begin{array}{l}\text { ASTM D } 3175 \text { (1), ISO } 562 \text { (2), ASTM } \\
\text { D1762 (3), ASTM E872 (4), CEN/TS } 15148 \\
\text { (5) }\end{array}$ & $\begin{array}{l}\text { 1-Channiwala \& Parikh (2002); 2-Debdoubi et al. (2005); 3- } \\
\text { Suárez et al. (2000); 4-Jenkins et al. (1998); 5-Miranda et al } \\
\text { (2012) }\end{array}$ \\
\hline $\begin{array}{l}\text { Nhuchhen \& Salam } \\
\text { (2012) }\end{array}$ & $\begin{array}{l}\text { ASTM D } 3175 \text { (1), ASTM E872 (2), ISO } 562 \\
\text { (3), ASTM D1762 (3), CEN/TS } 15148 \text { (3) }\end{array}$ & 1-Channiwala \& Parikh (2002); 2-Demirbaş (1997); 3-Yin (2011) \\
\hline Uzun et al. (2017) & $\begin{array}{l}\text { ASTM D } 3175 \text { (1), ASTM E872 (2),ISO } 562 \\
\text { (3), ASTM D1762 (3), CEN/TS } 15148 \text { (3) }\end{array}$ & 1-Parikh et al. (2005); 2-Demirbaş (1997); 3-Yin (2011) \\
\hline $\begin{array}{l}\text { Hosseinpour et al } \\
(2017)\end{array}$ & $\begin{array}{l}\text { ASTM D } 3175, \text { ASTM E } 872, \text { ISO } 562, \\
\text { ASTM D } 1762, \text { CEN/TS } 15148\end{array}$ & Nhuchhen \& Salam (2012) \\
\hline
\end{tabular}

Source: Authors (2021).

As an example, in the higher heating value model proposed by Uzun et al. (2017) in its database it is possible to find data from wheat straw that were made in accordance with the ASTM D3175 (2011) and another with the ASTM E872 (1982). To arrive at the proposed model, it would not be prudent for them to establish single standard to collect data on volatile matter.

As the content of volatile materials represents the most representative fraction (makes up more than 50\%) of the residual biomass, the objective of the work was to verify if there is a difference between the use of different standards for the determination of the volatile matter.

\section{Methodology}

\section{Biomass information}

Three residual biomasses widely used in industrial boilers in Brazil were chosen. The biomass of eucalyptus sawdust (Eucalyptus urograndis) was collected in the municipality of Itu (SP) and represents the energy material used by the Pulp and Paper sector. The pine sawdust (Pinus elliottii) was collected in Sorocaba (SP) and represents the biomass energy used by the Wood Panel industries. And the sugarcane bagasse (Saccharum officinarum) was collected in Porto Feliz (SP) and represents the biofuel used by the Sucro-Alcooleiras plants.

\section{Biomass collection}

Five kilos of each residual sample were collected, which were dried in an oven $\left(60^{\circ} \mathrm{C} \pm 2 \mathrm{hrs}\right)$ in order to decrease the high humidity. Then, the biomasses were packed in polyethylene bags at room temperature. The particle reduction of the biomass was carried out separately in a Willey knife mill (Marconi, model: MA 340). The particle separation was carried out with a set of screens coupled to an orbital screen shaker (Marconi, model: model MA 750). The size particle range obtained was adjusted according to the requirements of the standards used.

\section{Determination of the content of volatile matter}

The standards ASTM D1762, ASTM E872, ASTM D3175 and ISO 18123 were used as treatment conditions, totaling four treatments. These were obtained from the collection of the Coordination of Superior Level Staff Improvement (CAPES). For the determination of the volatile matter, samples dried at $105^{\circ} \mathrm{C}\left( \pm 2^{\circ} \mathrm{C}\right)$ were used until a constant mass was obtained. 
A muffle (Jung brand, model 0212) was used with a horizontal entrance and also with a vertical entrance option. For each test, a gram per sample was used. They were placed in crucibles with a lid. These had previously been calcined at $700^{\circ} \mathrm{C}$ for 30 minutes.

All stages of the analyzes followed the different requirements of each adopted standard. This included different patterns of granulometry, temperature, time, positioning inside the equipment and direction of sample entry (Table 2).

Table 2. Summary of tested standards for determining the volatile matter.

\begin{tabular}{llccc}
\hline Treatments: & Specification: & Granulometry $($ mesh $)$ & Temperature $\left({ }^{\circ}\right.$ C) & Time (min) \\
\hline ASTM E872** & Wood particles & $0<x \leq 18$ & $950 \pm 20$ & $(3) 7$ \\
ASTM D1762* & Charcoal & $0<x \leq 20$ & $950 \pm 05$ & $(1) 2,(2) 3,(3) 6$ \\
ASTM D3175** & Coal and Coke & $0<x<60$ & $950 \pm 20$ & $(3) 7$ \\
ISO 18123* & Solid biofuels & $0<x \leq 18$ & $900 \pm 10$ & (3) 7 \\
\hline
\end{tabular}

Legend: Values in parentheses indicate the position of the crucibles in the muffle: on the muffle lid (1); inner edge of the muffle (2); inside the closed muffle (3). Horizontal entrance muffle $(*)$. Vertical entry muffle $(* *)$.

Source: Authors (2021).

To reach the final value of the content of volatile matter, all standards eliminate the moisture of the material at temperatures close to the boiling point of water. Thus, in order to simplify the different formulas used and converge in the same equation, the following formula was adopted:

$$
\boldsymbol{V} \boldsymbol{M}(\%)=\left(\frac{m_{f}-m_{i}}{m_{i}}\right) x(100)
$$

on what: $\mathrm{VM}=$ volatile matter $(\%) ; \mathrm{mi}=$ initial dry mass $(\mathrm{g}) ; \mathrm{mf}=$ mass after the end of the analysis $(\mathrm{g})$.

The type of statistical methodology for experimental used was the design was completely randomized (Barbin, 2013), consisting of four treatments and five replications for each biomass.

\section{Central limit theorem of literature data}

The volatile matter information was extracted from Yin's databases (2011); Nhuchhen \& Salam's databases (2012); Uzun et al.'s databases (2017) and Hosseinpour et al's databases (2017). Then the central limit theorem test was applied (Morettin, 2010), using the Shapiro-Wilk test. Subsequently, three references from each author were randomly drawn and the test was applied separately per reference. To select the sample references, a minimum number of five samples collected from the same source were used as criteria.

\section{Results and Discussion}

The highest volatile matter was found when the ASTM E872 (2013) standard was used. The lowest value was evident when using the ASTM D1762 (2013) standard (Table 3). 
Table 3. Descriptive statistics of the different standards used to determine the volatile matter. Coefficient of Variation (C.V.).

\begin{tabular}{|c|c|c|c|c|c|}
\hline Biomasses: & Treatments: & Mean (\%) & C.V. $(\%)$ & Maximum & Minimum \\
\hline \multirow{4}{*}{ Sugar cane bagasse } & ASTM E872 & $83,16^{\mathbf{c}}( \pm 0,55)$ & 0,67 & 83,74 & 82,40 \\
\hline & ASTM D1762 & $76,95^{a}( \pm 0,19)$ & 0,25 & 77,16 & 76,70 \\
\hline & ASTM D3175 & $77,16^{a}( \pm 0,45)$ & 0,59 & 77,61 & 76,61 \\
\hline & ISO 18123 & $81,60^{\mathbf{b}}( \pm 0,48)$ & 0,59 & 82,29 & 81,01 \\
\hline \multirow{4}{*}{ Eucalyptus sawdust } & ASTM E872 & $79,94^{\mathrm{d}}( \pm 0,50)$ & 0,63 & 80,54 & 79,33 \\
\hline & ASTM D1762 & $72,81^{a}( \pm 0,43)$ & 0,59 & 73,11 & 72,06 \\
\hline & ASTM D3175 & $76,64^{b}( \pm 0,15)$ & 0,19 & 76,80 & 76,44 \\
\hline & ISO 18123 & $77,88^{\mathrm{c}}( \pm 0,33)$ & 0,42 & 78,40 & 77,51 \\
\hline \multirow{4}{*}{ Pine sawdust } & ASTM E872 & $88,27^{\mathbf{c}}( \pm 0,27)$ & 0,31 & 88,64 & 87,97 \\
\hline & ASTM D1762 & $80,88^{a}( \pm 0,29)$ & 0,36 & 81,18 & 80,54 \\
\hline & ASTM D3175 & $87,75^{\mathrm{c}}( \pm 0,30)$ & 0,34 & 87,95 & 87,23 \\
\hline & ISO 18123 & $86,17^{\mathbf{b}}( \pm 0,30)$ & 0,35 & 86,70 & 85,96 \\
\hline
\end{tabular}

Legend: Means followed by the same letter, for the same biomass, do not differ statistically at the level of 5\% probability by the Tukey test. Source: Authors (2021).

ANOVA residues for each biomass group showed normal distribution (p-value> 0.05; Shapiro-Wilk test), as well as homogeneity of variance (p-value> 0.05; Bartlett test). Such results validated ANOVA for cane bagasse, eucalyptus and pine. The null hypothesis, that there was no difference between the standards, was ruled out at the $0.01 \%$ significance level for all biomasses. That is, the tests showed that there is a statistically significant difference in the content of volatile matter for the tested standards.

The Tukey test revealed that for cane bagasse only the ASTM D1762 (2013) and ASTM D3175 (2011) standards were found to be the same. The other standards have shown to differ, at the level of 5\% significance. As for the Pinus biomas s, only the ASTM E872 (2013) and ASTM D3175 (2011) standards were found to be the same, and different for the others. In the test with eucalyptus sawdust, all standards were found to be different from each other at the 5\% level of significance.

Still, considering the averages obtained (table 2) as medians and applying the acceptable limit of values among the duplicates of the norms, according to each norm, it was observed that only sugarcane bagasse would present overlapping values. Specifically in the range of ASTM D1762 (2013) and ASTM D3175 (2011) (Table 04). In the other cases, it was evident that there would be no overlapping of values when following what was established by each standard worked.

Table 4. Maximum and minimum values of the analyzes obeying the amplitude described by the different used norms.

\begin{tabular}{|c|c|c|c|c|}
\hline & ASTM D1762 & ASTM E872 & ASTM D3175 & ISO 18123 \\
\hline Amplitude of standards (\%) & $\mathbf{0 , 5 0}$ & $\mathbf{0 , 3 0}$ & $\mathbf{0 , 2 0}$ & $\mu^{*} 0,01$ \\
\hline Sugar cane bagasse (\%) & $76,70<\mu<77.20$ & $83,01<\mu<83,31$ & $77,06<\mu<77,26$ & $81,19<\mu<82,00$ \\
\hline Eucalyptus sawdust (\%) & $\overline{72,56<\mu<73,06}$ & $79,79<\mu<80,09$ & $\overline{76,54<\mu<76,74}$ & $77,49<\mu<78,27$ \\
\hline Pine sawdust (\%) & $80,63<\mu<81,13$ & $88,12<\mu<88,42$ & $87,65<\mu<87,85$ & $85.74<\mu<86,60$ \\
\hline
\end{tabular}

Legend: $\mu=$ mean.

Source: Authors (2021).

It is noteworthy that the standards suggest the use of only duplicates, and when one wants to compare results with 
other different biomasses this would make it impossible to use independent hypothesis tests, in addition to making the evidence of the reproducibility of the main results questionable (Vaux et al., 2012). Only ISO 18123 (2015) suggests the use of more than two samples in the analysis, specifying a tolerable range of analyzes from the difference of $1 \%$ of the average of the analyzes and not as a basis for duplicates.

The results showed that the determination of the content of volatile materials can vary from standard to standard and also from biomass to biomass. ISO 18123 (2015) or ASTM E872 (2013) are recommended for fresh lignocellulosic materials. These are the most suitable standards for the biomass used, that is, non-pyrolyzed material. The ASTM D1762 (2013) and ASTM D3175 (2011) standards are suggested for pyrolyzed materials and fossil fuels, therefore, not suitable for raw materials. It is important to confirm this information, as there are studies in the literature that did not follow these recommendations [Yin, 2011; Nhuchhen \& Salam, 2012; Uzun et al., 2017; Hosseinpour et al., 2017).

Thus, gathering information on the content of volatile matter from different sources, without a standardization of standards can produce unreliable results. In the literature, it is not uncommon to find articles that collect and group contents of volatile materials without considering the most appropriate standard (Yin, 2011; Uzun et al., 2017; Hosseinpour et al., 2017; Sheng \& Azevedo, 2005).

As an example, it can be mentioned adjustments of models to determine higher heating values that used the content of volatile materials in the model. It was observed that the data for the independent variable (volatile content) did not present a normal data distribution (Table 05). This may indicate that the procedures did not take place under the same conditions. That is, the use of different standards results in different averages. Hurting an important principle of statistics in defining the design of an experiment (Barbin, 2013; Quinn \& Keough, 2010, Morettin, 2010).

Table 5. Results of the Shapiro-Wilk test. When the p-value is greater than 0.05 it is understood that the data have normal distribution.

\begin{tabular}{|c|c|c|c|c|}
\hline \multirow{3}{*}{$\begin{array}{l}\text { database: } \\
\text { Yin (2011) }\end{array}$} & \multicolumn{4}{|c|}{ p-value: } \\
\hline & All & Jenkins et al. (1998) & $\begin{array}{c}\text { Channiwala } \\
\text { and Parikh (2002) }\end{array}$ & $\begin{array}{c}\text { Tortosa Masiá } \\
\text { et al. (2007) }\end{array}$ \\
\hline & $\underline{0.003}$ & 0.290 & 0.193 & 0.294 \\
\hline \multirow{2}{*}{ Nhuchhen and Salam (2012) } & All & Demirbas (1997) & $\begin{array}{l}\text { Küçükbayrak } \\
\text { et al. (1991) }\end{array}$ & $\begin{array}{l}\text { Thipkhunthod } \\
\text { et al. (2005) }\end{array}$ \\
\hline & $2.2 \mathrm{x} \mathrm{e}^{-16}$ & 0.529 & 0.868 & 0.724 \\
\hline \multirow{2}{*}{ Uzun et al. (2017) } & All & $\begin{array}{l}\text { Channiwala and } \\
\text { Parikh (2002) }\end{array}$ & $\begin{array}{l}\text { Demirbas } \\
\text { (1997) }\end{array}$ & $\begin{array}{l}\text { Küçükbbayrak } \\
\text { et al. (1991) }\end{array}$ \\
\hline & $5.01 \mathrm{x} \mathrm{e}^{-11}$ & 0.060 & 0.330 & 0.997 \\
\hline
\end{tabular}

Source: Authors (2021).

When the data were extracted from different sources and grouped in the same database, the volatile matter content data did not meet the central limit theorem. Such theorem attests that with the increase of samples, the average tends to have a normal distribution (Quinn, 2010), a fact that was not observed in the total database of the authors mentioned. However, when analyzing each source unitarily, that is, according to each extracted source, it is possible to observe that the data meet the central limit theorem, as the data are made according to a specific standard. Only in the data from Hosseinpour et al (2017) it was not possible to cross-check the information from the different data sources. The data did not inform the references of each sample linked to the papers extracted.

Such information reinforces that as the standards presented different averages, that is, they result in different sampling methodologies, thus, they cannot be compared as the same. Because they tend to cause an error bias between them and interfere with the theory of the central limit of the data when they are given as equals. 
Also, consider a census to measure the height of a population with two different instruments. If one of the instruments is biased, any differences found between the populations may be related not to the actual differences in height of the people, but to parameters not equivalent to the ruler used (Nimon \& Reio Jr., 2011)

In short, this same interpretation can be used when different standards are applied to measure the same variable. Thus, the content of volatile matter showed that different standards function as different instruments, thus offering values that cannot be compared with each other. They are only comparable to each other when the values are obtained by the same standards.

Thus, as the range of information and data has increased, it is important to check the consistency of the database, especially when the extracted variables are not authored. Because occasionally, a database may offer numerical values for the same variable, but it is necessary to check at the source if the data are equivalent. As an example to compare data from a variable in centimeters and another in inches, it is necessary to perform a conversion before grouping the data in the same vector base. Without this, any model created from this variable is incoherent and questionable.

\section{Conclusion}

The volatile matter content has changed depending on the pattern used. Each standard has its particularities that can interfere with the results. Thus, to compare the content of volatile matter in a material (with data from the literature), it should be filtered for the same standard to be used.

In future works, it is important to observe whether the same error was made with the ash content. Mainly in works on estimating HHV as a function of proximate analysis. It is important to check if the author fixed the same standard, or if mixed several standards.

\section{Acknowledgments}

This study was financed in part by the Coordenação de Aperfeiçoamento de Pessoal de Nível Superior - Brasil (CAPES) - Finance Code 001.

\section{References}

American Society of Testing Materials (2013). D1762: Standard Test Method for Chemical Analysis of Wood Charcoal. West Conshohocken.

American Society of Testing Materials (2011). D3175: Standard Test Method for Volatile Matter in the Analysis Sample of Coal and Coke. West Conshohocken.

American Society of Testing Materials (2013). E872: Standard Test Method for Volatile Matter in the Analysis of Particulate Wood Fuels. West Conshohocken.

Barbin, D. (2013). Planejamento e Análise Estatística de Experimentos Agronômicos. ESALQ.

Channiwala, S. A., \& Parikh, P. P. (2020). A unified correlation for estimating HHV of solid, liquid and gaseous fuels. Fuel. 81 (8): $1051-63$.

Debdoubi, A., El Amarti, A., \& Colacio, E. (2005). Production of fuel briquettes from esparto partially pyrolyzed. Energy Conversion and Management. 46(11-12): 1877-84.

Demirbaş, A. (1997) Calculation of higher heating values of biomass fuels. Fuel. 76 (5): 431-34.

García, R., Pizarro, C., Lavín, A. G., \& Bueno, J. L. (2012). Characterization of Spanish biomass wastes for energy use. Bioresource Technology. 103(1): 249258.

Hansted, A. L. S., Nakashima, G. T., Martins, M. P., Yamamoto, H., \& Yamaji, F. M. (2016). Comparative analyses of fast growing species in different moisture content for high quality solid fuel production. Fuel. 184(15): 180-84.

Hosseinpour, S., Aghbashlo, M., Tabatabaei, M., \& Mehrpooya, M. (2017). Estimation of biomass higher heating value (HHV) based on the proximate analysis by using iterative neural network-adapted partial least squares (INNPLS). Energy. 138(1): 473-79.

International Organization for Standardization (2015). EN-ISO 18123: Solid biofuels: Determination of the content of volatile matter. 
Jenkins, B. M., Baxter, L. L., Miles, J. R., \& Miles, T. R. (1998). Combustion properties of biomass. Fuel Processing Technology. 54(1-3): 17-46.

Küçükbayrak, S., Dürüs, B., Meríçboyu, A. E., \& Kadiog̈lu, E. (1991) Estimation of calorific values of Turkish lignites. Fuel. 70(8): 979-81.

Miranda, M. T., Arranz, J. I., Rojas, S., \& Montero, I. (2009). Energetic characterization of densified residues from Pyrenean oak forest. Fuel. 88 (11) 210612.

Morettin, P. A. (2010). Estatística básica: probabilidade, inferência, volume único. $1^{\text {a }}$ ed. São Paulo: Pearson.

Nakashima, G. T., Adhmann, I. C. S., Hansted, A. L. S., Belini, G. B., Waldman, W. R., \& Yamaji, F. M. (2017). Materiais Lignocelulósicos: Caracterização e Produção de Briquetes. Revista Virtual de Química. 9(1): 150 - 62.

Nimon, K. \& Reio Jr, T. G. (2011). Measurement invariance: a foundational principle for quantitative theory building. Human Resource Development Review. 10(2): 198-14.

Nhuchhen, D. R. \& Salam, P. A. (2012). Estimation of higher heating value of biomass from proximate analysis: A new approach. Fuel. 99 : 55-63.

Nogueira, L. A. H., Lora, E. E. S., Trossero, M. A, \& Frisk, T. (2000). Dendroenergia: Fundamentos e Aplicações. Brasília: AEEL,

Özyuğuran, A., \& Yaman, S. (2017). Prediction of Calorific Value of Biomass from Proximate Analysis. Energy Procedia. 107: $130-36$.

Obernberger, I., \& Thek, G. (2004). Physical chatacterisation and chemical composition of densified biomass fuels with regard to their combustion behavior. Biomass and Bioenergy. 27(6): $653-69$.

Parikh, J., Channiwala, S. A., \& Ghosal, G. K. (2005). A correlation for calculating HHV from proximate analysis of solid fuels. Fuel. 84(5): 487-94.

Posom, J., Shrestha, A., Saechua, W., \& Sirisomboon, P. (2016). Rapid non-destructive evaluation of moisture content and higher heating value of Leucaena leucocephala pellets using near infrared spectroscopy. Energy. 107(15): 464-72.

Quinn, G. P. \& Keough, M. J. (2010). Experimental Design and Data Analysis for Biologists. Cambridge University Press.

Sheng, C., \& Azevedo, J. L. T. (2005). Estimating the higher heating value of biomass fuels from basic analysis data. Biomass and Bioenergy. $28(5)$ : 499-07.

Smith, A. K. G., Alesi, L. S., Varanda, L. D., Silva, D. A., Santos, L. O., \& Yamaji, F. M (2019). Production and evaluation of briquetes from urban pruning residue and sugarcane bagasse. Rev. Bras. Eng. Agríc. Ambiental. 23(2): 138-43.

Suárez, J. A., Luengo, C. A., Felfli, F. F., Bezzon, G., \& Beatón, P. A. (2000). Thermochemical Properties of Cuban Biomass. Energy Sources. 22(10): 85157.

Thy, P., Esbensen, K. H., \& Jenkins, B. M. (2009). On representative sampling and reliable chemical characterization in thermal biomass conversion studies. Biomass and Bioenergy. 33(11): 1513-19.

Thipkhunthod, P., Meeyoo, V., Rangsunvigit, P., Kitiyanan, B., Seimanond, K., \& Rirksomboon, T. (2005). Predicting the heating value of sewage sludges in Thailand from proximate and ultimate analyses. Fuel. 84 (7-8): 849-57.

Tortosa Masiá, A. A., Buhre, B. J. P., Gupta, R. P., \& Wall, T. F. (2007). Characterising ash of biomass and waste, Fuel Processing Technology. 88(11-12): $1071-81$.

Uzun, H., Yildiz, Z., Goldfarb, J. L., \& Ceylan, S. (2017) Improved prediction of higher heating value of biomass using an artificial neural network model based on proximate analysis. Bioresource Technology. 234: 122-30.

Vaux, D. L., Fidler, F., \& Cumming, G. (2012). Replicates and repeats--what is the difference and is it significant? A brief discussion of statistics and experimental design. EMBO reports. 13: 291-96.

Yang, X., Wang, H., Strong, J., Xu, S., Liu, S., Lu, K., Sheng, K., Guo, J., Che, L., He, L., Ok, Y. S., Yuan, G., Shen, Y., \& Chen, X. (2017). Thermal Properties of Biochars Derived from Waste Biomass Generated by Agricultural and Forestry Sectors. Energies. 10(4): 469-81.

Yin, C. Y. (2011). Prediction of higher heating values of biomass from proximate and ultimate analyses. Fuel. 90 (3): 1128-32.

Zhang, Z., Zhang, Y., Zhou, Y., Ahmad, R., Pemberton-Pigott, C., Annegarn, H., \& Dong, R. (2017). Systematic and conceptual errors in standards and protocols for thermal performance of biomass stoves. Renewable and Sustainable Energy Reviews. 72: $1343-54$. 